\title{
PERBANDINGAN NORMA PRODUKSI ISLAM DENGAN PRODUKSI PADA INDUSTRI BORDIR DI KECAMATAN BANGIL (STUDI KASUS PADA PERUSAHAAN FAIZA BORDIR)
}

\author{
Wandha Cholifah Ramadan \\ Mahasiswa Program Studi Ekonomi Islam-Fakultas Ekonomi dan Bisnis-Universitas Airlangga \\ Email: wandha.cholifah-12@feb.unair.ac.id \\ Suherman Rosyidi \\ Departemen Ekonomi Syariah-Fakultas Ekonomi dan Bisnis-Universitas Airlangga \\ Email: srosyidi@gmail.com
}

\begin{abstract}
:
This research aims to find out how far the implementation of Islamic production norms at Faiza Embroidery Industry in Bangil goes on. Author only implements two of four Islamic production norms, which are: to make working as a main pillar of production and to do production activity in a halal way. It uses qualitative approach by using case study method. Deep interview and observation to informen, were used in collecting data and they are owner and employees of this industry. Secondary data were derived from journal, text books, and the other literatures. Analysis has been done by seeing a suitability between activity of the production process and Islamic production norms. It is started from finance and then to labor, salary system, and materials used.
\end{abstract}

Keywords: Islamic Production, Islamic Production Norms, Embroidery Industry, Bangil

\section{PENDAHULUAN}

Manusia pada dasarnya memiliki kebutuhan dan keinginan. Apabila kebutuhan manusia terbatas, maka lain halnya dengan keinginan manusia yang tidak terbatas. Keinginan yang tidak memiliki batas tersebut sebagian besar berkaitan dengan barang atau produk yang ingin dimiliki. Produk merupakan bagian dari hasil produksi. Produksi adalah bagian terpenting di samping konsumsi dan distribusi (Rosyidi, 2014:45). Chaudry (2012:48) mendefinisikan produksi sebagai proses penciptaan guna dan penambahan nilai pada guna itu.

Islam mendeskripsikan produksi dengan istilah yang lebih luas, yakni melakukan eksplorasi alam semesta dengan tujuan memakmurkan bumi maupun melakukan eksplorasi alam semesta dengan tujuan memakmurkan bumi maupun melakukan pekerjaan atau kegiatan produksi. Harahap,dkk (2015:55) menyatakan bahwa:

Tujuan produksi dalam Islam adalah memenuhi kebutuhan diri, memenuhi kebutuhan masyarakat, keperluan masa depan, keperluan generasi akan datang, dan pelayanan terhadap masyarakat.

Salah satu tokoh ekonomi Islam yang cukup concern dengan teori produksi adalah Imam Al Ghazali. Beliau telah menguraikan faktor-faktor produksi dan fungsi produksi dalam kehidupan manusia (Karim, 2007:102). Dalam uraiannya beliau sering menggunakan kata kasab dan islah.

1] Jurnal ini merupakan bagian dari skripsi dari Wandha Cholifah Ramadan, NIM: 041211433067, yang diuji pada tanggal 17 Februari 2017 
Yang pertama berarti usaha fisik yang dikerahkan manusia, dan yang kedua berarti upaya manusia untuk mengelola dan mengubah sumber-sumber daya yang tersedia agar mempunyai manfaat yang lebih tinggi.

Al-Ghazali memberikan perhatian yang cukup besar ketika menggambarkan bermacam ragam aktifitas produksi dalam masyarakat, termasuk hierarki dan hakikatnya. Faktor utamanya adalah tentang jenis aktivitas yang sesuai dengan dasar-dasar etos kerja dalam Islam (Karim, 2007:104).

As-Sadr (2008:393) menyatakan bahwa:

Aktivitas produksi memiliki dua aspek, yaitu aspek objektif dan aspek subjektif. Aspek objektif terdiri atas sarana-sarana yang digunakan, kekayaan alam yang diolah, dan kerja yang dicurahkan dalam aktivitas produksi. Di sisi lain, aspek subjektif terdiri atas motif psikologis, tujuan yang hendak dicapai lewat aktivitas produksi, dan evaluasi aktivitas produksi menurut berbagai konsepsi keadilan yang dianut.

Seperti yang telah disebutkan diatas, contoh aspek objektif adalah ketika produsen memproduksi suatu barang harus memikirkan jumlah tenaga kerja dan modal yang dibutuhkan supaya dapat diperoleh hasil yang maksimal, sedangkan contok aspek subjektif adalah ketika produsen memproduksi suatu barang, bertujuan untuk menyediakan kebutuhan konsumen dan mencapai keuntungan secara maksimal.

Mengkaji dari teori produksi Islam dari prinsip pertumbuhan produksi, dapat diketahui bahwa Islam telah memerintahkan masyarakat muslim untuk membentuk perilaku mereka sesuai dengan apa yang telah ditentukan.

Sementara itu terdapat beberapa kegiatan produksi yang dilarang oleh Islam karena tidak memberikan manfaat bagi kehidupan manusia. Di antara yang terlarang tersebut adalah harga penjualan anjing, upah pelacuran, dan upah perdukunan. Semua keterangan di atas menunjukkan betapa Islam sangat menekankan pentingnya norma-norma produksi Islam. Islam menggariskan agar keseluruhan norma tersebut diperhatikan oleh para agen ekonomi (Harahap,dkk, 2015:58).

Proses produksi dimulai dari input dan diakhiri dengan output. Namun, apabila ditelaah lebih jauh, proses produksi dinyatakan dalam tahap-tahap produksi (stages of production) yang mencakup lima kegiatan, yaitu input, cara mendapatkan input, proses produksi, sistem imbalan dan distribusi output (Rosyidi, 2014:49).

Dari kelima tahapan produksi yang telah disampaikan, dipilih proses produksi sebagai topik utama yang akan membahas lebih dalam mengenai industri rumah tangga bordir karena berkaitan dengan penerapan kegiatan produksi secara Islam. Industri bordir yang diteliti adalah Faiza Bordir terletak di Kecamatan Bangil Kabupaten Pasuruan, Jawa Timur.

Melalui program Bangkodir (Bangil Kota Bordir) yang ditetapkan oleh pemerintah Pasuruan, para pengusaha kecil mikro menengah di sentra tersebut berupaya keras untuk terus menerus 
meningkatkan kualitas produk mereka, supaya dapat bersaing dengan produk bordir daerah lain seperti Malang dan Tasikmalaya.

Berdasarkan latar belakang di atas, maka penelitian ini akan mengkaji dan menganalisis secara kritis mengenai norma maupun aturan produksi dalam Islam dalam kegiatan produksi yang akan difokuskan dan diarahkan kepada bahan yang digunakan dan jenis-jenis produk yang dihasilkan.

Berdasarkan uraian yang telah dijelaskan, terdapat rumusan masalah sebagai berikut; Bagaimana penerapan norma-norma produksi Islam terhadap Perusahaan Faiza Bordir di Kecamatan Bangil?

Adapun tujuan penelitian ini antara lain; untuk mengetahui penerapan normanorma produksi Islam terhadap Perusahaan Faiza Bordir di Kecamatan Bangil.

\section{TINJAUAN PUSTAKA}

Mengutip Ruggles dan Ruggles, Rosyidi (2014:55) menjelaskan bahwa "In broader terms any process that creates value or adds value to already existing goods is production." Dengan perkataan lain produksi tidak hanya terdiri dari kegiatan membuat barang saja, melainkan juga meliputi kegiatan membuat jasa.

Sementara itu mengenai hal yang sama, dari ulama salafpun dapat kita temui definisi serupa. Menurut Fauzia dan Riyadi (2014:116) Al-Ghazali menjelaskan bahwa "Produksi adalah pengerahan secara maksimal sumber daya alam (raw material) oleh sumber daya manusia, agar menjadi barang yang bermanfaat bagi manusia." Dalam definisi tersebut, AlGhazali menekankan pentingnya pengerahan input "secara maksimal". Dari pada lain, beliau lebih menekankan pada arti penting input, baik sumber daya alam maupun sumber daya manusia. Al-Ghazali juga menambahkan pentingnya produksi sebagai upaya manusia untuk menambah nilai input tersebut sehingga "bermanfaat bagi manusia".

Dari kedua definisi di atas, dapat disimpulkan bahwa produksi memiliki unsurunsur (i) penciptaan dan penambahan nilai suatu barang dan (ii) tujuan akhirnya adalah menghasilkan output yang bermanfaat bagi manusia atau konsumen. Produksi menurut Islam adalah "Proses mencari, mengalokasikan dan mengolah sumber daya menjadi output dalam rangka meningkatkan maslahah bagi manusia. Oleh karena itu, produksi juga mencakup aspek tujuan kegiatan menghasilkan output serta karakter yang melekat pada proses dan hasilnya" (P3UI, 2014:230).

At-Tariqi (2004:159) menjelaskan bahwa:

produksi dalam Islam memiliki arti sebagai bentuk usaha keras dalam pengembangan faktor-faktor sumber yang diperbolehkan dan melipatgandakan income dengan tujuan kesejahteraan masyarakat, menopang eksistensi serta ketinggian derajat manusia.

Faktor produksi adalah input yang digunakan dalam proses produksi. Menurut 
Khan (1994:192) dalam ilmu ekonomi konvensional, terdapat empat faktor produksi yaitu:

(i) Tanah (yang mencakup mineral, air dan sumber daya alam lainnya).

(ii) Tenaga kerja

(iii) Modal: ini bukan modal dalam bentuk vang. Yang dimaksud modal di sini adalah alat produksi buatan manusia, seperti bangunan, pabrik, mesin dan peralatan yang dipakai untuk menghasilkan barang dan jasa. Modal tanpa tenaga kerja tidak mungkin dapat menghasilkan output.

(iv) Pengusaha: ini adalah sumberdaya manusia khusus, yang mengkoordinasikan penggunaan modal, tanah dan tenaga kerja untuk menghasilkan output. Pengusaha memiliki tugas yang barangkali paling berat, yakni mengambil keputusan.

Kerangka Islam hanya mengenal

dua kategori faktor produksi, yakni:

(i) Entrepreneurial factors of production (EFP) yang hanya menerima laba karena mau menanggung risiko.

(ii) Hired factors of production (HFP) yang hanya menerima ujrah (sewa atau upah) dan tidak mengandung risiko.

Produksi memiliki bidang-bidang yang berkaitan dengan sumber yang dianjurkan menurut Al-Qur'an dan AsSunnah (Hakim, 2012:75).

1. Perdagangan (tijarah)

Perdagangan adalah usaha produktif utama yang telah dicontohkan oleh Nabi SAW dan para sahabat. Islam amat mengapresiasi pedagang sebagai salah satu sarana pertukaran hak milik. Mengenai hal ini, Allah berfirman dalam Surat An-Nisa ayat 29:

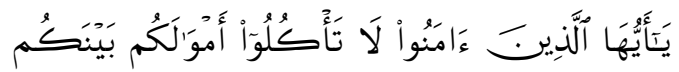

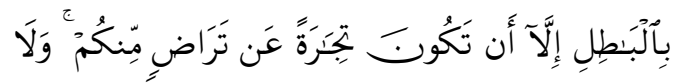

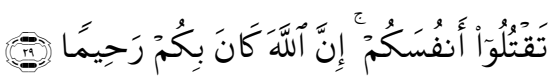

Artinya: Hai orang-orang yang beriman, janganlah kamu saling memakan harta sesamamu dengan jalan yang batil, kecuali dengan jalan perniagaan yang Berlaku dengan suka sama-suka di antara kamu. dan janganlah kamu membunuh dirimu; Sesungguhnya Allah adalah Maha Penyayang kepadamu.

2. Pertanian dan Perkebunan

Pertanian adalah kegiatan pengembangan pemanfaatan sumber daya hayati terutama tanaman produktif yang menghasilkan. Perkebunan adalah sistem pertanian dengan bahan non makanan pokok.

3. Industri

Bekerja mengolah sesuatu (bahan mentah) menjadi suatu barang yang bermanfaat bagi manusia atau dengan istilah lain merupakan usaha produksi yang diperbolehkan dalam Islam.

Al-Qur'an dan Hadis Rasulullah SAW memberikan arahan mengenai prinsipprinsip produksi sebagai berikut:

1. "Tugas manusia di muka bumi sebagai khalifah Allah adalah memakmurkan bumi dengan ilmu dan amalnya". Allah menciptakan manusia sebagai pemimpin di muka bumi untuk mensejahterakan kehidupan bumi dengan menggunakan ilmu dan amal yang dimiliki.

2. "Islam selalu mendorong kemajuan di bidang produksi. Islam mendukung perkembangan di bidang produksi melalui metode-metode tersebut". Islam mendukung perkembangan di bidang produksi melalui metodemetode tersebut.

3. "Teknis produksi diserahkan kepada keinginan dan kemampuan manusia". Proses produksi diserahkan kepada manusia karena (i) dirasa manusia lebih mengerti persoalan yang dihadapi, (ii) 
permasalahan dunia umumnya, dan produksi pada khususnya, senantiasa berkembang dari masa ke masa, dan (iii) bukan merupakan perkara agama yang menjadi hak mutlak Allah dan RasulNya.

4. "Dalam berinovasi dan bereksperimen pada prinsipnya agama Islam menyukai kemudahan, menghindari mudharat dan memaksimalkan manfaat". Dengan perkataan lain, Islam mengajarkan agar inovasi dan eksperimen berorientasi kepada proses dan output.

Adapun kaidah-kaidah dalam produksi adalah:

1. "Memproduksi barang dan jasa yang halal pada setiap tahapan produksi." Dengan perkataan lain, halal merupakan syarat utama dan pertama bagi proses produksi di semua tahapannya.

2. "Mencegah kerusakan di muka bumi, termasuk membatasi polusi, memelihara keserasian, dan ketersediaan sumber daya alam." Ini adalah kaidah yang amat penting, yaitu menjaga bumi agar terhindar dari kerusakan yang diakibatkan oleh kegiatan produksi. Proses produksi tidak dilaksanakan dengan mengorbankan.

3. "Produksi dimaksudkan untuk memenuhi kebutuhan individu dan masyarakat serta mencapai kemakmuran." Kaidah ini menegaskan kaidah "output oriented" yang telah dinyatakan di dalam prinsip keempat. Hanya saja, ditegaskan disini bahwa output tersebut harus membawa manfaat tidak hanya yang bersifat individualistik melainkan juga untuk masyarakat.

4. "Produksi dalam Islam tidak dapat dipisahkan dari tujuan kemandirian umat." Kegiatan produksi dalam Islam berkaitan dengan kemandirian masyarakat, yakni dimaksudkan agar setiap proses produksi dapat meningkatkan daya tahan dan daya saing masyarakat, sehingga dapat mengurangi ketergantungan kepada pihak lain.

5. "Meningkatkan kualitas sumber daya manusia baik kualitas spiritual maupun mental dan fisik." Inilah kaidah yang membedakan produksi Islami dengan yang lain, yakni proses produksi haruslah mampu meningkatkan (i) kesadaran akan dan ketergantungan kepada Allah semata, (ii) pengakuan akan kekuasaan dan kasih sayang Allah.

Tujuan Produksi menurut Islam memiliki empat tujuan, yaitu:

(i) pemenuhan sarana kebutuhan meskipun produsen hanya menghasilkan barang dan jasa yang menjadi kebutuhan dan bukan keinginan. (ii) kuantitas produksi tidak berlebihan, tetapi hanya sebatas kebutuhan yang wajar. (iii) sikap yang berorientasi pada kehidupan masa mendatang. Dan tujuan terakhir yaitu (iv) pemenuhan sarana bagi kegiatan sosial dan ibadah kepada Allah (P3El, 2014:233).

Sebagai penjelasan mengenai tujuan kegiatan produksi, gambar di bawah ini diharap dapat menjelaskan kegiatan konsumsi dan produksi menurut pandangan Islam. 
Sumber : Pusat Pengkajian dan Pengembangan Ekonomi Islam. 2014. Ekonomi Islam. Jakarta:Rajawali Pers.

Dari skema di atas dapat diketahui bahwa produsen dan konsumen memiliki peran, sebagaimana produsen berperan dalam proses menghasilkan barang dan jasa, sedangkan konsumen berperan dalam memanfaatkan barang dan jasa. Kegiatan tersebut dilakukan untuk mencapai maslahah (tujuan/manfaat) sehingga tercipta falah (kemuliaan).

Dalam gambar di atas, baik produsen maupun konsumen didasarkan oleh kebutuhan untuk melakukan kegunaan dan peran masing-masing. Tujuan akhir dari kegiatan produsen dan konsumen adalah menghasilkan (untuk produsen) dan memanfaatkan (untuk konsumen) maslahah. Pada akhirnya diharapkan bahwa sepasang kegiatan ini akan mencapai falah.

$$
\text { Nasution, dkk }
$$

menjelaskan bahwa nilai-nilai Islam yang relevan dengan produksi dikembangkan dari tiga nilai utama dalam ekonomi Islam, yaitu khalifah, adil dan takaful. Secara lebih rinci nilai-nilai Islam dalam produksi meliputi:
1. Berwawasan jangka panjang, yaitu berorientasi kepada tujuan akhirat.

2. Menepati janji dan kontrak, baik dalam lingkup internal atau eksternal.

3. Memenuhi takaran, ketepatan, kelugasan, dan kebenaran.

4. Berpegang teguh pada kedisiplinan dan dinamis.

5. Memuliakan prestasi atau produktifitas.

6. Mendorong ukhuwah antar sesama pelaku ekonomi.

7. Menghormati hak individu.

8. Mengikuti syarat sah dan rukun akad transaksi.

9. Adil dalam bertransaksi.

10. Memiliki wawasan sosial.

11. Pembayaran upah tepat waktu dan layak.

12. Menghindari jenis dan proses produksi yang diharamkan dalam Islam.

Menurut Qardhawi (1997:117)

berikut ini apa-apa saja produksi yang dilarang dalam Islam, yaitu:

1. Menanam tanaman yang diharamkan karena berbahaya bagi manusia seperti, poppy dari buah opium, cannabis atau heroin, ganja, narkotika, tembakau, chorome untuk dijadikan liquid, anggur jika diniatkan untuk membuat wine (minuman keras).

2. Memproduksi barang-barang haram, baik haram dikenakan ataupun haram dikoleksi. Misalnya, membuat patung atau cawan dari bahan emas dan perak, membuat gelang emas untuk laki-laki

3. Produk yang merusak akidah, etika dan moral manusia seperti, produk yang berhubungan dengan kemusyrikan, pornografi dan sadisme, baik dalam opera, film dan musik. 
Definisi industri menurut UU No. 3 Tahun 2014 tentang Perindustrian adalah seluruh bentuk kegiatan ekonomi yang mengolah bahan baku dan/atau memanfaatkan sumber daya industri sehingga menghasilkan barang yang mempunyai nilai tambah atau manfaat lebih tinggi, termasuk jasa industri.

Bordir diambil dari istilah dalam bahasa Inggris embroidery yang berarti sulaman. Bordir atau sulaman merupakan suatu teknik dengan media benang yang dijalinkan pada bidang berupa kain atau kulut dengan menggunakan jarum. Tujuannya membentuk suatu motif untuk menghias (Suhersono, 2004:6).

Norma adalah aturan yang berlaku dimasyarakat. Menurut Mu'in (2004:110) norma adalah patokan perilaku dalam suatu kelompok masyarakat tertentu. Keberadaan norma dalam masyarakat bersifat memaksa individu atau suatu kelompok agar bertindak sesuai dengan aturan sosial yang telah terbentuk sejak lama.

Norma merupakan hasil buatan manusia sebagai makhluk sosial. Pada awalnya, aturan itu dibentuk secara tidak sengaja. Lama-kelamaan norma-norma itu disusun dan dibentuk secara sadar. Norma dalam masyarakat berisi tata tertib, aturan, petunjuk standar perilaku yang pantas atau wajar.

Menurut Qardhawi (1997:99), pembahasan terkait norma produksi adalah sebagai berikut:

1. Perhatian Al-Quran terhadap sumber daya alam
Allah telah menciptakan alam untuk manusia. Jika kita renungkan di dalam Al-Qur'an, bahwa Allah menganjurkan kepada kita untuk menggunakan sumber-sumber kekayaan alam seperti air, udara, lautan, sungai, tumbuh-tumbuhan, hewan dan benda mati; matahari dan bulannya, siang dan malam, semua itu diciptakan untuk diambil manfaatnya oleh manusia.

2. Bekerja sendi utama produksi

Bekerja adalah segala usaha maksimal yang dilakukan manusia baik lewat gerak anggota tubuh ataupun akal untuk menambah kekayaan. Bekerja merupakan sendi utama dalam kegiatan produksi. Oleh karena itu, Islam menganjurkan umatnya untuk memproduksi dengan berbagai bentuk aktifitas ekonomi, yaitu pertanian, perindustrian, dan perdagangan.

3. Berproduksi dalam lingkaran halal

Prinsip etika dalam produksi wajib dilaksanakan oleh setiap muslim baik individu maupun komunitas adalah berpegang pada semua yang dihalalkan Allah dan tidak melampaui batas. Seperti contohnya tidak menanam apa yang diharamkan seperti pohon ganja dan segala tumbuhan yang menurut WHO, sains dan hasil riset berbahaya bagi manusia.

4. Perlindungan kekayaan alam

Setiap hamba wajib mensyukuri nikmat yang diberikan Allah dan salah 
satu cara mensyukuri nikmat adalah dengan menjaga sumber daya alam dari polusi, kehancuran atau kerusakan. Islam menghendaki semua tenaga dikerahkan untuk meningkatkan produktifitas lewat itqan (ketekunan) yang diridhai oleh Allah atas segala sesuatu.

\section{METODOLOGI PENELITIAN}

\section{Pendekatan Penelitian}

Pendekatan yang digunakan dalam penelitian ini adalah pendekatan kualitatif yang bertujuan untuk menjawab rumusan masalah secara mendalam dan memerlukan pengumpulan data melalui wawancara, observasi di lapangan dan dokumentasi.

Metode yang dipilih adalah studi kasus karena hasil penelitian dengan metode ini sulit untuk dimanipulasi karena tidak adanya peluang bagi peneliti untuk memprediksi peristiwa-peristiwa yang akan terjadi.

\section{Rancangan Penelitian}

Yin (2009:29) menyebutkan bahwa terdapat lima komponen desain penelitian untuk studi kasus sebagai berikut.

a. Pertanyaan penelitian

Pertanyaan penelitian berawal dari bagaimana mengarahkan penelitian ini memakai studi kasus sebagai metode penelitian. Studi kasus paling cocok digunakan untuk pertanyaan "how" atau "why". Pertanyaan penelitian yang digunakan yaitu: bagaimana penerapan norma-norma produksi Islam terhadap indutri bordir di Kecamatan Bangil?

b. Proposisi

Proposisi penelitian mengarahkan peneliti untuk tetap fokus kepada ruang lingkup yang harus diteliti, sehingga peneliti akan memperoleh bukti yang relevan dalam penelitian. Proposisi dalam penelitian ini adalah produksi sesuai prinsip Islam pada industri bordir yang ada di Kecamatan Bangil, memiliki peran serta manfaat bagi kehidupan dan kesejahteraan baik produsen, konsumen maupun pekerja di lingkungan sekitar.

c. Unit analisis

Unit analisis adalah hal yang berkaitan dengan aspek apa saja yang diteliti. Berkaitan dengan rumusan masalah pada penelitian ini, maka yang menjadi unit analisis dalam penelitian ini adalah penerapan norma-norma produksi Islam pada industri bordir di Kecamatan Bangil.

d. Logika yang mengaitkan data dengan proposisi tersebut

Data yang dikumpulkan dan diperoleh harus mengacu pada proposisi yang akan berguna sebagai bahan analisis, sehingga dapat memberikan informasi untuk menjawab pertanyaan penelitian mengenai penerapan norma-norma produksi Islam pada industri bordir di Kecamatan Bangil.

e. Kriteria untuk menginterpretasi temuan

Melalui temuan yang diperoleh diharapkan dapat memberikan 
gambaran yang cukup jelas bagi penelitian ini. Tujuan akhir penelitian ini adalah mengetahui apakah normanorma produksi yang berlaku sesuai ajaran Islam. Apabila sudah, hendak diketahui pula sejauh mana normanorma produksi Islami tersebut telah diterapkan pada industri bordir di Kecamatan Bangil.

\section{Ruang Lingkup Penelitian}

Ruang lingkup penelitian merupakan batasan studi yang memfokuskan pada suatu penelitian. Penelitian ini fokus pada penerapan norma-norma produksi Islam pada industri bordir Faiza di Kecamatan Bangil Kabupaten Pasuruan. Adanya penerapan norma-norma produksi Islam pada Faiza Bordir, dapat terhindar dari hal-hal yang menyimpang dari ajaran Islam.

\section{Jenis dan Sumber Data}

Jenis Data

Dalam skripsi ini digunakan data yang di dapat dari dua sumber data, yaitu data primer dan sekunder.

a. Data primer

Data primer yang dijadikan sumber dalam penelitian ini di peroleh langsung dari lapangan adalah wawancara, observasi, dan dokumentasi pada pengrajin Faiza Bordir di Kecamatan Bangil.

b. Data sekunder

Data sekunder diperoleh dari studi literatur yang diperoleh dari beberapa buku tentang produksi menurut ekonomi Islam, jurnal, internet dan sumber lainnya yang relevan.

\section{Sumber Data}

Data primer dalam penelitian ini diperoleh dari hasil wawancara dan observasi di lapangan, sedangkan data sekunder diperoleh dari data yang sudah ada dan berkaitan dengan penelitian berupa laporan-laporan dan dokumen yang relevan serta berkaitan dengan permasalahan.

\section{Teknik Pemeriksaan Keabsahan Data}

Penelitian ini hanya menggunakan triangulasi dengan sumber data. Triangulasi dengan sumber data dilakukan dengan membandingkan data hasil pengamatan dengan hasil wawancara. Dalam penelitian ini, penulis akan mewawancarai pemilik bordir dan pengrajin bordir untuk mendapatkan data yang akurat dan valid.

\section{Teknik Analisis Data}

Miles dan Hubberman dalam buku Sugiyono (2010:246), mengemukakan bahwa analisis dengan menggunakan analisis model interaktif dilakukan melalui tiga prosedur, yaitu:

1. Reduksi Data

$$
\text { Mereduksi data berarti }
$$

merangkum, memilih hal-hal yang pokok, memfokuskan pada hal-hal penting, dicari tema dan polanya. Dengan demikian data yang telah direduksi akan memberikan gambaran yang lebih jelas dan mempermudah peneliti untuk melakukan pengumpulan data selanjutnya apabila diperlukan. 
2. Penyajian Data

Setelah data direduksi, maka langkah selanjutnya adalah mendisplaykan data. Dalam hal ini Miles dan Huberman dalam Sugiyono (2010:249) menyatakan bahwa yang paling sering digunakan dalam penelitian kualitatif adalah dengan teks yang bersifat naratif.

3. Penarikan Kesimpulan

Kesimpulan awal yang dikemukakan masih bersifat sementara, dan akan berubah bila tidak ditemukan bukti-bukti yang kuat yang mendukung pada tahap pengumpulan data berikutnya. Tetapi apabila kesimpulan yang dikemukakan pada tahap awal, didukung oleh buktibukti yang valid dan konsisten saat peneliti kembali ke lapangan mengumpulkan data, maka kesimpulan yang dikemukakan merupakan kesimpulan yang kredibel.

Analisis data yang dilakukan dalam penelitian ini yaitu melihat sejauh mana penerapan norma-norma produksi Islam pada industri Faiza Bordir yang telah dilakukan.

\section{HASIL DAN PEMBAHASAN}

\section{Penerapan Norma Produksi Islam pada} Perusahaan Faiza Bordir

Berdasarkan hasil wawancara yang telah dilakukan, maka akan dijelaskan dan dideskripsikan hasil dan jawaban dari seluruh informan yang telah diwawancarai. Hasil yang perlu dicatat adalah bahwa keempat norma produksi dalam Islam yang disampaikan oleh
Qardhawi di Bab II adalah norma umum untuk semua cabang produksi. Dengan demikian dapat dipahami bahwa tidak setiap cabang produksi memiliki kaitan dengan keempat norma produksi tersebut. Dalam hubungan dengan Faiza Bordir, cabang produksi ini hanya berkaitan dengan norma kedua dan ketiga yaitu (a) bekerja merupakan sendi utama produksi dan (b) berproduksi dalam lingkaran halal. Berikut perbandingan analisis penerapan norma produksi Islam dengan produksi di Faiza Bordir dalam tabel 4.2.

Tabel 4.2

Perbandingan Norma Produksi Islam dengan Produksi Faiza Bordir

\begin{tabular}{|c|c|c|}
\hline No & $\begin{array}{l}\text { Norma Produksi } \\
\text { Islam }\end{array}$ & $\begin{array}{c}\text { Kegiatan Faiza } \\
\text { Bordir }\end{array}$ \\
\hline 1 & $\begin{array}{l}\text { Perhatian Al- } \\
\text { Qur'an terhadap } \\
\text { sumber daya } \\
\text { alam }\end{array}$ & 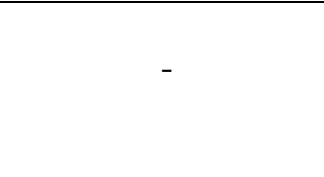 \\
\hline 2 & $\begin{array}{l}\text { Bekerja sendi } \\
\text { utama produksi } \\
\text { a. Jenis } \\
\text { pekerjaan } \\
\text { b. Barang dan } \\
\text { Jasa }\end{array}$ & $\begin{array}{l}\text { a. Membordir dan } \\
\text { menjahit } \\
\text { barang-barang } \\
\text { bordir } \\
\text { b. Memproduksi } \\
\text { kebaya bordir, } \\
\text { home } \\
\text { decoration } \\
\text { bordir, gamis } \\
\text { atau jubah } \\
\text { bordir, dan } \\
\text { baju takwa } \\
\text { bordir. }\end{array}$ \\
\hline 3 & $\begin{array}{l}\text { Berproduksi } \\
\text { dalam lingkaran } \\
\text { halal } \\
\text { a. Modal } \\
\text { b. Tenaga Kerja } \\
\text { c. Pengupahan } \\
\text { d. Bahan yang } \\
\text { digunakan } \\
\text { e. Peruntukan } \\
\text { f. Pola dan } \\
\text { Desain }\end{array}$ & $\begin{array}{l}\text { a. Modal yang } \\
\text { digunakan } \\
\text { melalui bank } \\
\text { konvensional } \\
\text { dan mitra } \\
\text { usaha industri } \\
\text { konvensional } \\
\text { b. Diberi waktu } \\
\text { istirahat sholat } \\
\text { dan pakaian } \\
\text { menutup aurat }\end{array}$ \\
\hline
\end{tabular}




\begin{tabular}{|c|c|c|}
\hline & & $\begin{array}{l}\text { c. Upah yang } \\
\text { diberikan setiap } \\
\text { hari Sabtu } \\
\text { d. Bahan yang } \\
\text { digunakan } \\
\text { halal, seperti } \\
\text { kain, benang } \\
\text { dan manik- } \\
\text { manik } \\
\text { e. Diperuntukkan } \\
\text { bagi wanita } \\
\text { dan laki-laki, } \\
\text { baik muslim } \\
\text { maupun non } \\
\text { muslim } \\
\text { f. Pola dan } \\
\text { desain yang } \\
\text { digunakan } \\
\text { tidak menyimpang } \\
\text { dari ajaran } \\
\text { Islam seperti } \\
\text { bunga }\end{array}$ \\
\hline 4 & $\begin{array}{l}\text { Perlindungan } \\
\text { kekayaan alam }\end{array}$ & - \\
\hline
\end{tabular}

kegiatan Faiza Bordir sehari-hari, baik pemilik maupun pekerja telah menerapkan norma produksi dalam Islam yang kedua yaitu menjadikan produksi bordir sebagai sendi utama dalam kegiatan produksi yaitu memproduksi kebaya bordir, batik dan tenun, home decoration, gamis atau jubah, baju takwa dan kain kebaya. Sedangkan apabila dikaitkan dengan norma produksi yang ketiga, proses produksi yang ada di Faiza Bordir tidak sepenuhnya berproduksi dalam lingkaran halal, seperti menggunakan modal yang berasal dari mitra usaha industri konvensional dan bank konvensional.

Kedua persoalan ini memerlukan penjelasan agak rinci sesuai dengan tujuan dilakukannya penelitian ini. Norma yang kedua yakni bekerja sebagai sendi utama mengandung beberapa pokok persoalan yaitu: (a) jenis pekerjaan, (b) barang dan jasa. Mengenai norma ketiga yakni berproduksi dalam lingkaran halal, terdapat pula beberapa hal yang menyangkut, (a) modal, (b) tenaga kerja, (c) pengupahan, (d) bahan yang digunakan, (e) peruntukan, (f) pola dan desain. Dibawah ini akan dijelaskan semua itu satu demi satu sejauh yang diterapkan oleh Faiza Bordir.

Analisis perbandingan produksi sesuai prinsip Islam dengan produksi di Faiza Bordir berdasarkan jenis pekerjaan dapat disimpulkan bahwa pekerjaan yang dilakukan di Faiza Bordir meliputi pengrajin seperti menjahit, menyulam dan membordir, dan penjaga toko Faiza Bordir yang bertugas melayani pembeli atau konsumen.

Sedangkan, analisis perbandingan produksi sesuai prinsip Islam dengan produksi di Faiza Bordir berdasarkan barang yang diproduksi meliputi kebaya bordir, home decoration bordir, gamis atau jubah bordir, dan baju takwa bordir. Barang-barang yang diproduksi Faiza Bordir sesuai dengan prinsip Islam karena tidak memproduksi barang-barang yang diharamkan oleh Islam.

Analisis perbandingan produksi sesuai prinsip Islam dengan produksi di Faiza Bordir berdasarkan permodalan dapat disimpulkan bahwa permodalan yang diperoleh untuk mendirikan Faiza Bordir berasal dari mitra usaha industri konvensional dan bank konvensional. Setiap bulan dikenakan tambahan biaya 
bunga sebesar $1 \%$ dari total pinjaman awal. Selain untuk mendirikan perusahaan, modal juga digunakan untuk memproduksi barang-barang halal seperti kebaya bordir, home decoration, gamis atau jubah, baju takwa dan kain kebaya. Modal diperoleh atas rekomendasi ibu Imam Utomo karena keperihatinan beliau terhadap usaha Faiza Bordir yang menyatu dengan rumah pemilik dan berukuran kecil sehingga sulit untuk dijangkau oleh pejabat tinggi yang datang dengan membawa kendaraan beroda empat. Seharusnya, permodalan yang sesuai dengan prinsip Islam, didapatkan melalui bank syariah, baitul mal wat tamwil dan pasar modal syariah dengan sistem bagi hasil untuk cicilan pembayaran setiap bulan.

Selanjutnya, analisis perbandingan produksi sesuai prinsip Islam dengan produksi di Faiza Bordir berdasarkan tenaga kerja, dapat disimpulkan bahwa para tenaga kerja diberikan waktu istirahat untuk sholat dan makan siang selama satu setengah jam pada pukul 11.30 - 13.00 . Para perkerja diberi kebebasan untuk memanfaatkan waktu istirahat sholat dzuhur dan makan siang di tempat kerja atau di rumah masing-masing, namun mereka harus kembali ke Faiza Bordir tepat pada pukul 13.00. Selain itu, pemilik Faiza Bordir membebaskan pakaian yang digunakan saat bekerja, namun para tenaga kerja memang sudah menutup aurat dengan berjilbab meskipun ada beberapa tenaga kerja yang berjilbab karena merasa segan berada di lingkungan kerja yang seluruh pekerja wanitanya menggunakan jilbab. Di sinilah terletak kelebihan Faiza Bordir, yaitu dapat menciptakan suasana kerja dengan nuansa Islami sehingga para pekerja mewajibkan dirinya untuk berpenampilan rapi dan menutup aurat saat bekerja.

Bagi pekerja eksternal, Faiza Bordir tidak memberi waktu istirahat khusus karena mereka bekerja di rumah sehingga memiliki waktu istirahat yang dapat dilakukan kapan saja. Sama halnya dengan waktu istirahat, pakaian yang digunakanpun bebas karena mereka hanya bekerja di rumah. Hanya saja ketika ada tamu yang datang ke rumah ingin memesan jahitan atau bordir, pakaian yang mereka gunakan tertutup dan menggunakan jilbab.

Selanjutnya, hasil analisis perbandingan produksi sesuai prinsip Islam dengan produksi di Faiza Bordir berdasarkan pengupahan menyimpulkan bahwa perusahaan tidak menunda waktu pemberian, karena dalam hadits riwayat Ibnu Majah ditulis "Berikan pekerja upahnya sebelum keringatnya kering". Hadits ini ditunjukkan kepada para pengusaha untuk memberikan upah kepada para pekerja tepat pada waktunya. Pemberikan upah dan vang makan bagi para pekerja setiap minggunya pada hari Sabtu menjelang waktu pulang, namun untuk pemberian upah sesuai dengan hasil pekerjaan yang dihasilkan oleh tiap pekerja. Menurut pandangan Islam tentang pengupahan berdasar kerja halal yaitu upah yang diberikan harus untuk 
pekerjaan halal dan tidak menyimpang dari prinsip Islam. Faiza Bordir memberikan upah untuk memproduksi kebaya bordir, home decoration, batik dan tenun, gamis atau jubah dan baju takwa.

Selain itu, sistem pengupahan yang dilakukan oleh Faiza Bordir kepada pekerja eksternal dibayarkan setiap minggu atau setiap bulan, tergantung pada jumlah pesanan bordir dan jahitan. Tugas yang dilakukan oleh pekerja eksternal Faiza Bordir hanya membordir dan menjahit kain kebaya dan kain batik saja.

Dari hasil analisis perbandingan produksi sesuai prinsip Islam dengan produksi di Faiza Bordir berdasarkan bahan yang digunakan dapat disimpulkan bahwa bahan-bahan yang digunakan Faiza Bordir didapatkan dan diproses dengan cara yang halal, serta berasal dari bahan-bahan halal. Contohnya seperti kain sutera, rayon, chiffon, katun, polyester, batik, batik yang berpayet, tenun, kain kebaya meliputi kain broklat, tile dan taffeta, benang dan manik-manik. Dalam prinsip Islam, proses produksi harus diperhatikan kehalalannya, mulai dari bahan-bahan yang digunakan, cara mendapatkan bahan, proses produksi, sistem imbalan yang diberikan setelah memproduksi bahan dan juga cara ataupun tujuan dalam menghasilkan bahan-bahan halal.

Adapun hasil analisis perbandingan produksi sesuai prinsip Islam dengan produksi di Faiza Bordir berdasarkan peruntukan barang-barang yang telah diproduksi. Faiza Bordir tidak menaruh perhatian terhadap produk yang dipesan oleh konsumen untuk diproduksi. Oleh karena itu, hasil produksi yang dihasilkan Faiza Bordir seperti kebaya bordir, batik dan tenun dan home decoration bordir dapat dikonsumsi baik muslim maupun non-muslim, namun untuk gamis atau jubah bordir, dan baju takwa bordir hanya dapat dikonsumsi oleh muslim.

$$
\text { Hasil analisis perbandingan }
$$
produksi sesuai prinsip Islam dengan produksi di Faiza Bordir berdasarkan pola dan desain. Islam menegaskan untuk tidak menggunakan pola dan desain yang menyimpang dari ajaran Islam, seperti gambar salib ataupun yang lain, namun selama Faiza Bordir berdiri belum pernah ada bordiran pola maupun desain yang menyimpang dari prinsip Islam, ataupun permintaan konsumen yang ingin menggunakan pola dan desain yang tidak sesuai dengan prinsip Islam.

\section{SIMPULAN}

Berdasarkan hasil dan pembahasan penelitian tersebut, dapat ditarik beberapa kesimpulan, yaitu:

1. Penerapan norma-norma produksi Islam pada industri bordir di Kecamatan Bangil (studi kasus pada perusahaan Faiza Bordir) belum sepenuhnya dilaksanakan sesuai dengan normanorma produksi Islam. Penerapan yang dilakukan oleh perusahaan Faiza Bordir menurut Qardhawi hanya norma kedua dan ketiga saja, yaitu: (ii) Bekerja merupakan sendi utama dalam 
produksi, dan (iii) Berproduksi dalam lingkaran halal.

2. Bekerja merupakan sendi utama produksi yaitu dilihat berdasarkan jenis pekerjaan dan barang atau jasa yang dihasilkan. Jenis pekerjaan yang ada di Faiza Bordir sesuai dengan norma produksi Islam yaitu, membordir dan menjahit barang-barang bordir, sedangkan barang yang diproduksi seperti kebaya bordir, home decoration bordir, gamis atau jubah bordir dan baju takwa bordir.

3. Berproduksi dalam lingkaran halal belum sepenuhnya diterapkan karena Faiza Bordir dalam mendapatkan pinjaman modal menggunakan mitra usaha industri konvensional dan bank konvensional yang menggunakan sistem bunga dalam penambahan biaya pada setiap cicilan pembayaran pengembalian modal.

\section{DAFTAR PUSTAKA}

Ash Shadr, Muhammad Baqir. 2008. Buku Induk Ekonomi Islam Iqtishaduna. Jakarta: Zahra Publishing House

At-Tariqi, Abdullah Abdul Husain. 2004. Ekonomi Islam Prinsip, Dasar dan Tujuan. Yogyakarta: Magistra Insania Press.

Chaudry, Muhammad Sharif. 2012. Sistem Ekonomi Islam Prinsip Dasar. Jakarta: Prenadamedia Group.

Fauzia, Ika Yunia dan Abdul Kadir Riyadi. 2014. Prinsip Dasar Ekonomi Islam Perspektif Maqashid al-syari'ah. Jakarta: Prenadamedia Group.

Hakim, Lukman. 2012. Prinsip-Prinsip Ekonomi Islam. Jakarta: Erlangga
Harahap, Isnaini dkk. 2015. Hadis-Hadis Ekonomi. Jakarta: Prenadamedia Group.

Karim, Adiwarman A. 2007. Ekonomi Mikro Islami. Jakarta: PT. RajaGrafindo Persada

Khan, M. Fahim. 1995. Essay in Islamic Economics. Terjemahan oleh Suherman Rosyidi. 2013. United Kigdom:The Islamic Foundation.

Mu'in, Idianto. 2004. Sosiologi Untuk SMA Kelas $X$. Jakarta:Erlangga.

Nasution, Mustafa Edwin dkk. 2006. Pengenalan Eksklusif Ekonomi Islam. Jakarta: Kencana.

Pusat Pengkajian dan Pengembangan Ekonomi Islam. 2014. Ekonomi Islam. Jakarta: Rajawali Pers.

Qardhawi, Yusuf. 1997. Norma dan Etika Ekonomi Islam. Jakarta: Gema Insani

Rosyidi, Suherman. 2014. Pengantar Teori Ekonomi. Jakarta: Rajawali Pers.

Sugiyono. 2010. Metode Penelitian Kuantitatif Kualitatif dan R\&D. Bandung: CV.Alfabeta

Suhersono, Hery. 2004. Desain Bordir Inspirasi Motif Bordir Cina. Jakarta: Gramedia Pustaka Utama.

Yin, Robert K. 2011 . Studi Kasus: Desain dan Metode. Edisi pertama. Cetakan sepuluh. Jakarta : Rajawali Press 